\title{
First In A Series
}

\section{Charting Our Changing Course}

\section{Society will play an increasing role in the use and management of the world's rangelands.}

\author{
By Urs P. Kreuter and Michael P. Schellenberg
}

Editor's Note: The International Affairs Committee sponsored a sympo sium entitled "Rangeland Professionals and Society: Future Directions" at the 2001 annual SRM meeting in Kona, Hawaii. From those presentations, a se ries of articles will be published in Rangelands over the next six months highlighting perspectives on rangelands from around the world. The editors and authors wish to thank Dow AgroSciences of Indianapolis, Indiana, for a grant made in support of the symposium.

As human populations have grown, societal values and uses of both public and private rangelands have shifted. In developed countries, increasing urbanization and declining returns from livestock have resulted in a growing interest in the recreational attributes, ecotourism potential and non-agricultural uses of rangelands rather than their agricultural attributes. By contrast, in many developing countries, rapid population growth coupled with adverse economic conditions has led to accelerated transformation of rangelands for agricultural production.

Contrasting with these changes there is widespread public perception that our profession focuses exclusively on livestock production despite the grow- ing diversity of disciplines represented by rangeland professionals.

A 1998 survey of members and nonmembers of the Texas Section of the Society for Range Management, found that the term "rangeland" conjured images of cows and grass in the overwhelming majority of both groups (Hart and Rollins 1999). Both members and non-members also predominantly saw livestock grazing as the most important issue affecting Texas rangelands and, in general, considered current rangeland condition to be worse than historical conditions.

In the face of changing societal demands for rangelands, such stereotypic views are negatively affecting the perceived ability of our profession to contribute in the future management of rangeland ecosystems and their resources. The consequences of such negative perceptions include a decline in professional career opportunities for rangeland specialists in public agencies, a decrease in public support for rangeland-related research, a reduction in contributions to rangeland journals and a drop in the membership of rangeland societies.

Membership statistics for the world's two largest professional rangeland so- cieties indicate that trend (See Table 1.) Both the Society for Range Management (SRM) of North America and the Australian Rangeland Society (ARS) experienced a sharp decline in total membership during the 1990s. In the SRM, membership reached a peak of 5,046 in 1992 but declined by $25 \%$ to 3,801 in 2001 . Note that the membership peak preceded the initiation of sweeping changes in public land management policies by the Clinton administration that favored preservation over utilization of these lands. In the ARS, membership declined by $52 \%$ from a high of 638 in 1989 to 420 in 2001.

Of just as much concern as dwindling membership is the internationally narrow representativeness of these societies; only about $2.5 \%$ of the SRM members are not from the USA while about $12 \%$ of the ARS members are from abroad (about $5 \%$ from the USA). Thus the interests of people inhabiting many of the worlds rangelands are not being effectively represented by any professional rangelandfocused organization. An exception occurs in South America, where the Asociacion Argentina de Manejo de

Table 1. Membership statistics of the Society for Range Management (SRM), and the Australian Rangeland Society (ARS)

\begin{tabular}{lrrrrrrrrrrrrr}
\hline Year & 1989 & 1990 & 1991 & 1992 & 1993 & 1994 & 1995 & 1996 & 1997 & 1998 & 1999 & 2000 & 2001 \\
\hline SRM & 4471 & 4608 & 4611 & 5046 & 4933 & 4843 & 4510 & 4411 & 4056 & 3827 & 3628 & 3846 & 3801 \\
ARS & 638 & 630 & 506 & 567 & 487 & 487 & 520 & 482 & 459 & 405 & 553 & 420 & 420 \\
\hline
\end{tabular}


Pastizales Naturales, consisting of nearly 300 members, was formed in May 1999 in response to the increasing need of rangeland-based livestock producers for a representative body.

\section{Addressing The Challenge}

To focus the global debate about the future of the rangeland profession and to prevent it from becoming increasingly marginalized in the natural resource management arena, the International Affairs Committee of SRM sponsored a symposium on the future role of rangeland professionals in the face of social change. This symposium was held on February 20, 2001 at the $54^{\text {th }}$ annual meeting of the SRM in Kona, Hawaii. The following articles are from that symposium. They offer a historical perspective of rangeland management and address the challenges that face future rangeland professionals in several rangeland-dominated countries. Most importantly, these articles identify several key skills future range professionals will need to adopt in order to serve rangelands and all the consumers of this diverse resource effectively.

Editors are assistant professor, Department of Rangeland Ecology and Management, Texas A\&M University, College Station, Tx., 77843-2126, USA; and biologist Semiarid Prairie Agricultural Research Center, Agriculture \& Agri-Food Canada, P.O. Box 1030, Swift Current, SK S9H $3 X 2$, Canada

\section{References}

Dobrowolski, J.P., 1992. The future of range education. Rangelands, 14(3):133-144.

Hart, C.R., and D. Rollins, 1999. Who knows the SRM in Texas? Who cares? Rangelands, 21(3):19-21.

McClaran, M.P. 2000. History of the range curriculum: Are there new trails? Rangelands, 22(6): 23-27.

Trlica, M.J., D.L. Drawe, J.A. Young, and P.F. McCawley, 2000. Attitudes about range research. Rangelands, 22(5):13-14.

\section{What's Been Said Before}

Future directions for rangeland research in North America have been discussed in the past. In 1997, SRM's Research Affairs Committee conducted a survey of SRM members (Trlica et al. 2000). Survey respondents indicated:

1) The most important short-term research issues were to develop new, practical ways for measuring range vegetation and initiate systems approaches to rangeland management and livestock production.

2) Important long-term (10-year) research issues included addressing ecological and economic sustainability, problems of increasing urbanization, and the need for social awareness.

In addition, survey respondents identified a broad array of environmental problems requiring study including biological diversity, ecological sustainability, and restoration ecology. Many considered land-use conflicts, wildlife, recreation, and urbanization as issues of growing importance. They also indicated a continuing need for research in core rangeland subjects including succession, rangeland health measurements, and grazing management.

Another workshop and a symposium held in 1991 and 1992 identified several critical areas needing attention for the effective education of rangeland professionals. (Dobrowolski 1992). Strategies for improvement included:

1) Providing students with training in basic skills and critically thinking rather than an abundance of highly specialized coursework;

2) Exposing graduate students to global-scale and socio-economic/human ecology issues while placing greater emphasis on ecosystem-level management, environmental issues, and alternative rangeland uses;

3) Providing continuing education opportunities for rangeland professionals in order to keep them informed about changing technologies, land uses, and values pertaining to rangeland resources; and

4) Expanding extension efforts into audiences beyond producers, rural homemakers and agricultural youth.

A review of rangeland curricula concluded that in North America curricula have grown in breadth, have become more standardized, and have set educational standards for federal employees, but that they need to address additional needs in order to remain current (McClaran 2000). In particular:

1) Curricula should be coordinated with non-traditional rangeland management employers to convince them that rangeland graduates are well trained resource managers;

2) Rigorous continuing education curricula should be developed and integrated into university structure;

3) Newly developed interdisciplinary natural resource curricula should not abandon the range discipline subject matter.

In addition to the preceding initiatives, joint meetings of related societies have been contemplated or attempted in part to address the dwindling attendance at conferences due to declining membership. The Society for Range Management and the American Forage and Grassland Council held a joint national conference in February 1999 to identify potential synergies between the two groups. At the international level, a proposal for a joint meeting of the International Rangeland Congress (IRC) and the International Grassland Congress (IGC) was discussed (but voted against) at the $1999 \mathrm{VI}^{\text {th }}$ International Rangeland Congress in Australia.

To increase the visibility of rangeland research worldwide and in response to declining contributions to national rangeland-related journals, the formation of an international rangelands journal is also being considered in the Australia, South Africa and the USA. 